\title{
Re-evaluating the margin of the South Australian grain belt in a changing climate
}

\author{
U. B. Nidumolu' ${ }^{1,2,}$, P. T. Hayman ${ }^{2}$, S. M. Howden ${ }^{3}$, B. M. Alexander ${ }^{2}$ \\ ${ }^{1}$ CSIRO Ecosystem Sciences/Climate Adaptation Flagship, CSIRO Adelaide Laboratories, Gate 4, Waite Rd, Urrbrae, \\ South Australia 5064, Australia \\ ${ }^{2}$ South Australian Research and Development Institute (SARDI) Climate Applications, GPO Box 397, Adelaide, \\ South Australia 5001, Australia \\ ${ }^{3}$ CSIRO Ecosystem Sciences/Climate Adaptation Flagship, GPO Box 284, Canberra, Australian Capital Territory 2601, \\ Australia
}

\begin{abstract}
The drier inland edge of the Australian grain belt, where wheat cropping transitions into extensive grazing, is an important economic and ecological margin. This margin is determined primarily by climate rather than topography or soil type. In South Australia a line drawn by the Surveyor General George Goyder in 1865 between land that was reliable for wheat growth and land that was unreliable has become an icon of land use planning. In this study we compare Goyder's Line with maps of pre-European vegetation, climate variables such as temperature, rainfall, ratio of precipitation to evaporation ( $P: E$ ratio), current land use as measured by the edge of grain farming in 2008 and crop simulation on a transect. Although Goyder's Line is a reasonable representation of the margin of reliable cropping in some regions, it is internally inconsistent and care should be used if interpreting it as an isopleth of crop production risk. A better fit to the South Australian and Australian grain belt was the ratio between rainfall $(P)$ during the growing season (April to October) and potential evaporation $(E)$ of 0.26 . The surprisingly close fit of this ratio with much of the Australian grain belt suggests a climatically determined hard edge to the cropping zone. The paper explores how the 0.26 P:E ratio may shift under projected changes in climate using 2 global climate models, one 'dry' and one 'wet'. We observe that the speed of change in $\mathrm{km}$ decade $^{-1}$ will be greater where the edge of grain farming is on extensive plains than in those areas where it is topographically determined.
\end{abstract}

KEY WORDS: Climate change $\cdot$ Shifting crop margins $\cdot$ Australian grain belt $\cdot$ Landuse change Risk management $\cdot$ Crop simulation model

Resale or republication not permitted without written consent of the publisher

\section{INTRODUCTION}

The role of climate in defining margins or edges of bioregions has long been a rich source of enquiry for ecology (Root et al. 2005, Crawford 2008, Rosenzweig et al. 2008). If climate is a key factor determining the boundary of a bioregion, it follows that a change in climate will lead to a shift of the boundary. A meta-analysis of global ecological data over the last century indicates a poleward shift in species distributions of $6 \mathrm{~km}$ decade ${ }^{-1}$ largely as a result of rising temperatures (Root et al. 2005). When existing spatial gradients of temperature are combined with climate change projections to calculate the velocity of boundary change in $\mathrm{km} \mathrm{yr}^{-1}$ (Loarie et al. 2009), there is a much greater spatial shift of margins on plains than mountains. The influence of climate in determining current and future agricultural land use has been studied through agro-climatic zones (Williams et al. 2002, Hutchinson et al. 2005), agro-ecoregions (Padbury et al. 2002) and the agro-ecological zone analysis (AEZ), the latter of which has been promoted by 
the United Nation's Food and Agricultural Organisation (FAO) (Fischer et al. 2002).

One of the most studied aspects of the interaction of climate and landuse in Australia is the location of the 'grain belt', a region where wheat and other cereals are grown, often in rotation with pastures grazed predominantly by sheep (Taylor 1918, Nix 1975, Williams et al. 2002). Australia is a large, flat continent with approximately concentric zones of rainfall that decrease with distance from the coastal fringe towards the extensive arid interior. Attention has focussed on the drier margins of the grain belt where cropping gives way to extensive grazing. This transition zone, which is highly sensitive to climate factors, especially rainfall, has not been static but has changed over time depending on sequences of good or poor cropping seasons and technology (Meinig 1962, Davidson 1981, Howden \& Reyenga 2001, Inakwu et al. 2011).

There has long been a fascination from the wider community with the margin between the arable and the desert; the safe 'inner' (i.e. closer to the coast) with more reliable rainfall and the dangerous northern 'outer' (i.e. further inland) with low, erratic rainfall, higher evaporation and high temperatures. According to Clark (1962), these margins exist in almost all grain growing regions of the world, but there are few cases where the history and identification is as well documented as in South Australia. South Australia was established as a colony on the southern edge of the Australian continent in 1836. The colony grew inland with significant expansion of cropping as a result of what, in hindsight, was a run of unusually wet seasons. The subsequent return to normal or below average rainfall resulted in major land degradation and economic and social disruption. After the severe drought during 1863 to 1866, the then Surveyor-General George Goyder established a line that marked areas of reliable and unreliable annual rainfall; this line came to be understood as a line beyond which cropping was unreliable (Reyenga et al. 2001, Sheldrick 2005). The history of Goyder's Line is elaborated in Meinig's (1962) book 'On the margins of the good earth' and Sheldrick (2005).

Goyder was instructed by the government to "lay down on the map, as nearly as practicable, the demarcation between the portion of the country where the rainfall has extended and the drought prevails' (Meinig 1961). The resultant line was more than the extent of the 1865 drought, as Goyder was guided by vegetation as an integrator of the mean and variability of climate, soil and topography. According to Taylor (1915), the line followed the south- ern boundary of 'salt bush, mulga and dwarf Mallee country'. In addition to vegetation, Goyder had access to the experience of local graziers, including the line drawn in 1858 by the pastoralist and parliamentarian George Hawker (Sheldrick 2005). Although limited, there were some rainfall records that had been collated by Charles Todd who arrived in Adelaide in 1855 (Rogers 2008).

Since Goyder's time, there have been a number of approaches to identify the climatically-determined edge of the grain belt. Taylor (1915) had the advantage of access to more extensive rainfall records than Goyder. He stated that the ideal for wheat was 15 inches $(375 \mathrm{~mm})$ annual rainfall with the extreme boundary found in South Australia as the 6 inch $(150 \mathrm{~mm})$ winter isohyet, which was estimated to be parallel and 25 miles $(40 \mathrm{~km})$ north of the 10 inch $(250 \mathrm{~mm}$ ) isohyet noting (in reference to the 15 inch isohyet): "This is considerably beyond Goyder's well known line, which was based on the native flora, and was indeed within the 10 inch $(250 \mathrm{~mm})$ line". Rainfall records are still used to identify margins. For example the Australian Natural Resources Atlas (ANRA 2001) uses the reliability of rainfall as an indicator of land use. For cereals it is assumed that a minimum of $20 \mathrm{~mm} \mathrm{mo}^{-1}$ for the $4 \mathrm{mo}$ of June to September is required (as distinct from the chances of receiving at least $80 \mathrm{~mm}$ of total rain in $4 \mathrm{mo}$ ).

In the 1930s, 3 researchers at the Waite Institute in Adelaide (J. A. Prescott, B. R. Davidson \& H. C. Trumble) built on the work from De Martonne (1926) to combine rainfall and evaporation. Trumble (1939) defined the limit of safe wheat growth in South Australia based on where May to September rainfall was $\sim 1 / 3$ of evaporation ( $P$ :E ratio of 0.3 ). Marshall (1973) combined the work of Trumble, Prescott and Davidson to produce a map based on what she called the Waite Index. French (1988) identified the April to October $P: E$ ratio of 0.26 based on Minnipa on the upper Eyre Peninsula (EP), where there is an agricultural research centre at the northern edge of the cropping belt (see Fig. 1). This ratio is broadly consistent with the 0.30 suggested by Trumble (1939).

An early simulation modelling approach to the Australian grain belt was by Nix (1975) who incorporated knowledge of wheat crop physiology to identify critical times when the crop was sensitive to moisture stress and frost risk. He also systematically allowed for different soil and farming systems such as in the northern agricultural regions of Australia where fallow storage of rainfall is important. Importantly, he incorporated risk on the basis that the limit of wheat 
production was as much an economic consideration as a physical one. Consequently, he represented the boundary of the grain belt as the region where stored soil moisture plus annual rainfall should exceed 6 inches $(150 \mathrm{~mm})$ in $8 \mathrm{yr}$ out of 10 . Nix concluded that this analysis would improve with better data and improved simulation models. Hammer et al. (1987) assessed potential expansion of cropping across the grain belt in SE Queensland using the daily time step soil moisture-crop modelling framework Agricultural Production Systems Simulator (APSIM). This modelling system has since been used to assess the changing risks of cropping under climate change and $\mathrm{CO}_{2}$ increase in northern New South Wales (NSW) (Howden \& Reyenga 2001) and across Goyder's Line in South Australia (Reyenga et al. 2001) and Western Australia (van Ittersum et al. 2003).

The purpose of this paper was to reflect on what Goyder's Line as an agro-ecological isopleth means in a climate that is variable and changing. We compared Goyder's Line with a number of climate variables such as rainfall, ratio of precipitation to evaporation ( $P: E$ ratio), current land use as measured by the edge of grain farming in 2008 and crop simulation on a transect. This study explores how the 'margin' might shift under projected changes in climate using 2 global climate models, one 'dry' and one 'wet', over Australia using the $P: E$ ratio isopleth as a reference.

\section{METHODS}

\subsection{Data}

Data used in this paper comprises of (1) Goyder's Line: archive of 1865 map was sourced from the erstwhile South Australian Department of Water and Land Conservation (www.archives.sa.gov.au/exhibits/ saonmap/geographer/rainline.html); (2) land cover map of 2008; (3) soils data, sourced from Primary Industries and Resources South Australia (PIRSA), with land cover and soils data at 1:50 000 scale; (4) a map of pre-European vegetation (DENR 2009); (5) climate surfaces sourced from Queensland Department of Primary Industries Silo database (Carter et al. 1996, Jeffrey et al. 2001) on a $5 \mathrm{~km}$ grid. The climate surface gridded data has been developed using the ground based observational data. Continuous daily time step records have been constructed using spatial interpolation algorithms to estimate missing data. Data sets have been constructed for daily rainfall, temperatures, evaporation, solar radiation and vapour pressure. For details regarding the accuracy of the interpolated data and spatial error analysis please refer to Jeffery et al. (2001); further information on this data set is also available at the Silo Patched Point dataset (www.longpaddock.qld.gov. $\mathrm{au} / \mathrm{silo} /$ ). For the simulation model APSIM (Keating et al. 2002), daily weather records were obtained from the Silo Patched Point dataset from 1900 to 2007. Climate change model data were accessed from OzClim Climate Change Scenario Generator ( 25 km spatial grids) (www.csiro.au/ozclim) using models from the Fourth Assessment of the Intergovernmental Panel on Climate Change (IPCC) (Ricketts \& Page 2007).

\subsection{Identifying the segments along Goyder's Line}

Previous studies on Goyder's Line have focussed on a single point (e.g. Minnipa) (French 1988) or a transect (Reyenga et al. 2001). In this study we took a spatial approach studying the line along the outer boundary of the South Australian grain belt (Fig. 1). Based on geographical regions and discussion with local farmers and agronomists, we identified 7 segments of Goyder's Line: (1) Western Eyre Peninsula (EP), (2) Eastern EP, (3) Upper Yorke Peninsula, (4) Southern Flinders Coastal Plain, (5) Upper North, (6) Eastern Fall and the (7) the Murray Mallee. Strips or buffers of $10 \mathrm{~km}$ width on either side of Goyder's Line were generated for each of the 7 segments for a distance $120 \mathrm{~km}$ north and $50 \mathrm{~km}$ south (Fig. 1). The buffers were used to extract data from the spatial layers indicated in the Data section. For the climate variables (viz. rainfall, evaporation, $P: E$ ratio), mean values during the growing season (April to October) were calculated for every $10 \mathrm{~km}$ buffer for each of the segments on either side of the line. For cropping areas, the percent area of crops in a particular strip or buffer was calculated, assuming that all the buffer area was potentially agricultural. For soils, percent area of a particular texture was calculated with reference to the $10 \mathrm{~km}$ strip or buffer.

\subsection{Generating $P: E$ ratio data}

The April-October growing season precipitation and evaporation data were generated by averaging daily climate surface data for 1970-2008 across Australia (evaporation data prior to 1970 are less reliable). The $0.26 P$ :E ratio was derived by dividing 


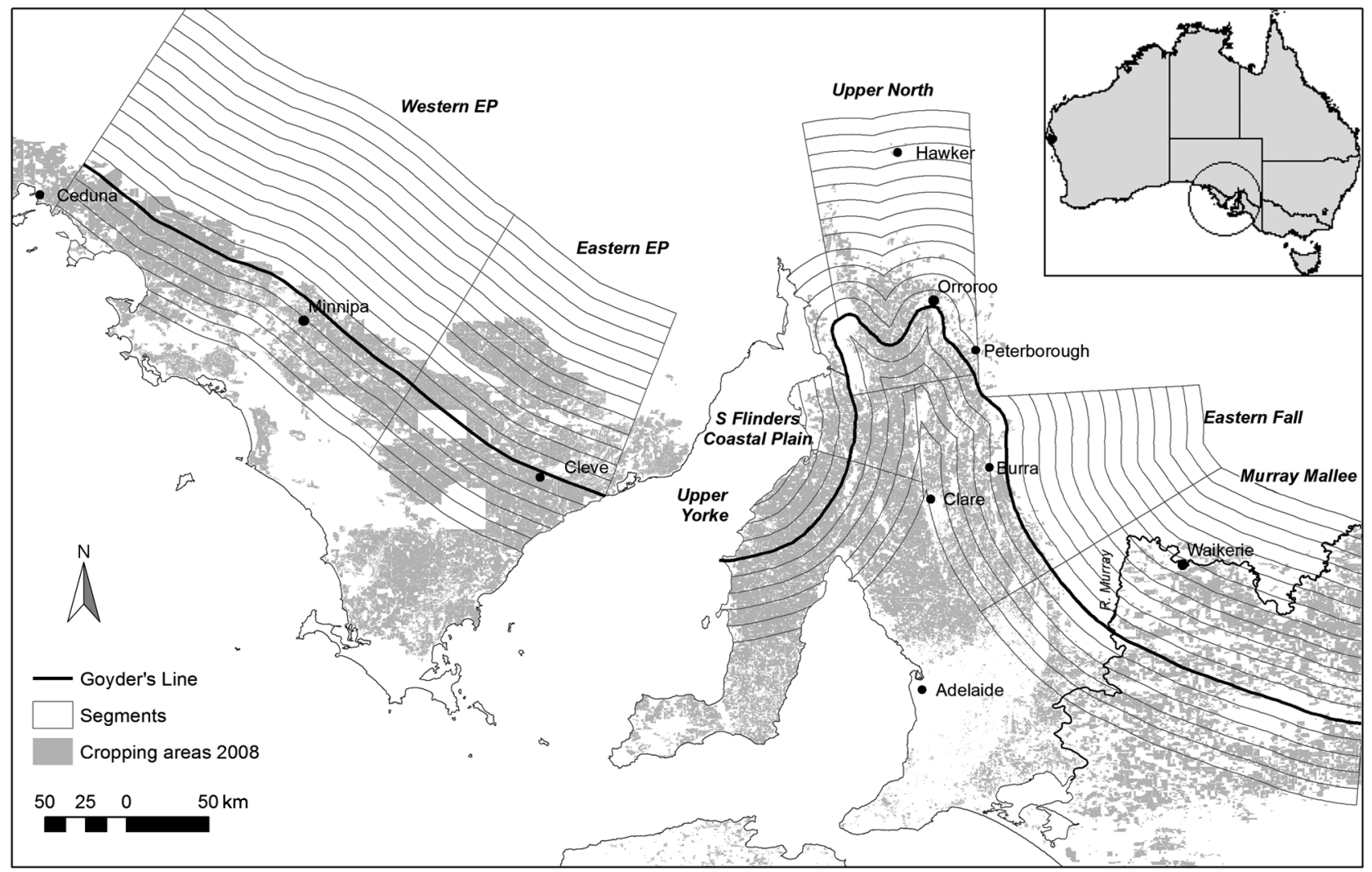

Fig. 1. Study area depicting Goyder's Line, $10 \mathrm{~km}$ buffers on either side of the line and cropping areas. EP: Eyre Peninsula, S Flinders: South Flinders

the $P$ by $E$ and generating an isopleth that could be used on the South Australian and the Australian grain belt.

\subsection{Crop simulation across transects on the segments}

The cropping simulation model APSIM is a point source model that uses climate data to simulate a daily soil water balance, daily crop growth and partitioning into harvestable yield. APSIM was used to investigate the range in simulated wheat yields for the generated buffer zones for the 7 segments. In this study our primary interest is the simulated effect of changes in climate across the 7 segments on relative wheat yield. APSIM has been validated in the southern Australian grain belt (e.g. Sadras et al. 2003, Yunusa et al. 2004, Whitbread \& Hancock 2008) and previously used for studies on climate variability (Hayman et al. 2010) and climate change in the region (Howden \& Reyenga 2001, Reyenga et al. 2001, Luo et al. 2005, Alexander \& Hayman 2008). Daily climate files from 1910 to 2008 were extracted from Silo Data Drill (Jeffrey et al. 2001; www.longpaddock.qld.gov.au/silo/) for every second buffer zone north and south of Goyder's Line as shown in Fig. 1, and are therefore $\sim 20 \mathrm{~km}$ apart. For a yield comparison, 3 soils were used. The first was a loam over medium-light clay (Morchard Plain No. 603) with plant available water capacity (PAWC) of $150 \mathrm{~mm}$ and organic carbon (OC) content of $0.74 \%$ in the top $25 \mathrm{~cm}$. This soil was classified in Morchard in the South Australia Upper North. The second soil classified in the upper EP was a sand (Mudamuckla No. 372b) with a PAWC of $40 \mathrm{~mm}$ and OC content of $0.64 \%$ in the top $10 \mathrm{~cm}$. The third soil was a Calcarosol described as a light loamy sand over a highly calcareous sandy loam. This was measured at Waikerie in the Murray Mallee and has a PAWC of $67 \mathrm{~mm}$ and $\mathrm{OC}$ content of $0.61 \%$ in the top $10 \mathrm{~cm}$ (Hayman et al. 2010). The 3 soils were selected to represent a range from finer texture (Morchard Plain) to coarser textured sand (Mudamuckla) across the low rainfall farming region in South Australia. Soil water, soil nitrogen and surface organic matter were reset each year on May 15 so that there were no carry-on effects from the previous season's crop, or any effect 
Table 1. Management settings used in APSIM runs across the Goyder's Line segments. SA: South Australia. PAWC: plant available water capacity

\begin{tabular}{|c|c|}
\hline Variable & Setting \\
\hline Rotation & Wheat-wheat \\
\hline Cultivar & Frame \\
\hline Sowing date & Fixed May 20 \\
\hline Sowing density; depth & 180 plants $\mathrm{m}^{-2} ; 40 \mathrm{~mm}$ \\
\hline Row spacing & $220 \mathrm{~mm}$ \\
\hline $\mathrm{N}$ fertiliser & $125 \mathrm{~kg} \mathrm{~N} \mathrm{ha}^{-1}$ (as urea) at sowing \\
\hline Soil water reset & May 15, $20 \mathrm{~mm}(30 \%$ PAWC) \\
\hline Soil N reset & May $15,<5 \mathrm{~kg} \mathrm{~N} \mathrm{ha}^{-1}$ \\
\hline Residue reset & May $15,1000 \mathrm{~kg} \mathrm{ha}^{-1}$ wheat stubble \\
\hline Climate & Silo Data Drill, 1910-2008 \\
\hline $\mathrm{CO}_{2}$ & 380 ppm \\
\hline Soil 1 & $\begin{array}{l}\text { Loam clay (Morchard, SA); PAWC } 150 \mathrm{~mm} \\
\text { - U = } 4 \\
\text { - Cona }=2.5 \\
\text { - Salb }=0.13 \\
\text { - DiffusConst }=88 \\
\text { - DiffusSlope }=35 \\
\text { - CN2Bare }=73\end{array}$ \\
\hline Soil 2 & $\begin{array}{l}\text { Sand (Upper Eyre Peninsula, SA); PAWC } 40 \mathrm{~mm} \\
-\mathrm{U}=4 \\
\text { - Cona }=2 \\
\text { - Salb }=0.13 \\
\text { - DiffusConst }=250 \\
\text { - DiffusSlope }=22 \\
\text { - CN2Bare }=73\end{array}$ \\
\hline Soil 3 & $\begin{array}{l}\text { Calcarosol (Waikerie, SA); PAWC } 67 \mathrm{~mm} \\
\text { - Summer U = } 6 \\
\text { - Winter U = } 2 \\
\text { - SummerCona }=3.5 \\
\text { - WinterCona }=2 \\
\text { - SummerDate = } 1-\mathrm{-Nov} \\
\text { - WinterDate = 1-Apr } \\
\text { - Salb }=0.13 \\
\text { - DiffusConst = } 250 \\
\text { - DiffusSlope }=22 \\
\text { - CN2Bare }=68\end{array}$ \\
\hline
\end{tabular}

age temperature and the slope of the regression equation gives the mean local change per degree of global warming. This conveniently decouples the local change from the emission scenario underlying the global warming. This means the local change can be scaled by a range of global warming values, for different times or different emission scenarios (Whetton et al. 2001, CSIRO 2007). The future climate change scenarios are thus very strongly related to the extent of future global warming as well as the pattern of change determined by the climate model examined.

For the purposes of this project, we sampled across both of those elements. Using Goyder's Line as a reference, possible shifts in the $P: E$ ratio under a changing climate were generated. This analysis was carried out using 2 models: CSIRO Mk 3.5 and CC MIROC-H, A1FI scenario under moderate sensitivity for the growing season period of April to October. These models were chosen on the availability of projection information, model performance in southern Australia (Suppiah et al. 2006) and patterns of future rainfall change. The CSIRO MK 3.5 model simulates a reduction in future rainfall or a drier future over Australia. The model projects a 10 to $20 \%$ reduction in growing season rainfall over South Australia for 2030. The CCR MIROC-H climate

from summer fallow. Available soil nitrogen from soil and fertiliser at sowing was set at $125 \mathrm{~kg} \mathrm{~N} \mathrm{ha}^{-1}$ leading to a nitrogen limit in about the wettest quarter of years. Table 1 provides the APSIM management settings.

\subsection{Climate change impacts on shift in $P: E$ ratios}

The OzClim scenario generator developed by Commonwealth Scientific and Industrial Research Organisation (CSIRO)'s Marine and Atmospheric Research and the International Global Change Institute was used to generate scenarios of future rainfall and evaporation change (www.csiro.au/ozclim; Ricketts \& Page 2007). In OzClim, regional scenarios are generated by linearly regressing the local seasonal mean temperature (or rainfall) against global aver- model produces a relatively 'wetter' future, simulating increased rainfall in eastern and mid-western Australia (up to $10 \%$ ) with decreases in rainfall in southern and northern Australia (0 to 5\%) (CSIRO 2007). $P$ :E ratio isopleths were generated from the CSIRO Mk3.5 and CC MIROC-H model data for 2030 and 2050 for the April-October period and overlaid on the current cropping areas and a transect of current climate $P$ : $E$ ratios.

\section{RESULTS}

\subsection{Current land use}

A comparison of Goyder's Line and the current cropping boundary (Fig. 1) shows that while in Western EP, Upper North and Eastern Fall there is 
good agreement; in other segments, cropping has extended well inland of Goyder's Line. In Upper Yorke cropping has extended to the Spencer Gulf, and in Murray Mallee it has extended to the Murray river with almost no cropping to the north of the river. Although vegetation was an important aspect of Goyder drawing his line, we could not find a strong relationship between boundaries of pre-European vegetation as represented at a state-wide scale and either Goyder's Line or the current boundary of cropping (DENR 2009) (data not shown). There is closer agreement in the Eastern Fall, but this is a case where there is a strong topographic influence that is linked to both soils and rainfall and hence vegetation.

Soils are highly spatially heterogeneous across most of the South Australian grain growing region. The dominant surface texture of soils on the EP and the Murray Mallee are sands or loams, whereas the Upper Yorke, South Flinders Coastal Plain and Upper North have a higher portion of soils with higher clay content (Maschmedt 2002). We could not find a change in soil type as an indicator for either Goyder's Line or the current extent of cropping when we calculated the dominant soil texture for each $10 \mathrm{~km}$ segment to the outside (north) and inside (south) of the line. In the Eastern Fall and South Flinders Coastal Plain segments there are differences in soils and vegetation across Goyder's Line, but these changes in soil and vegetation follow major topographic and geological changes associated with the Flinders Ranges. In these cases topography, not soil type, is the main determinant of land use.

\subsection{Rainfall as a ratio of evaporation}

The Southern Australian grain belt is set in a Mediterranean climate with a strong winter dominant rainfall. French (1988) observed that Minnipa on Eastern EP, the site of a low rainfall farming research station, had a winter growing season (April to October) rainfall of $220 \mathrm{~mm}$ (annual rainfall: $300 \mathrm{~mm}$ ) and a $P: E$ ratio for April to October of 0.26 . Although it is probable that French (1988) would have examined a number of sites, we cannot find any record of French drawing a line based on spatial climate data. When the $220 \mathrm{~mm}$ growing season rainfall isohyet and a $0.26 P: E$ isopleth are extended spatially from Minnipa, they follow the contours of the edge of the South Australian grain belt remarkably well (Fig. 2). For most of the grain belt, the $220 \mathrm{~mm}$ rainfall isohyet and the $P: E$ ratio are very similar. However in the Murray Mallee, the $220 \mathrm{~mm}$ rainfall isohyet is located well south of Goyder's Line, which in turn is south of the $0.26 P: E$ ratio line and the edge of cropping. It is the $0.26 P: E$ isopleth that follows the edge of cropping that extends up to the Murray River. Figs. $2 \& 3$ show the unexpected result that a single measure of $P: E$ ratio of 0.26 selected for Minnipa research station and based on Trumble's analysis in the 1930s explains the drier edge of much of the Australian grain belt. This simple measure shows a remarkable fit in Western Australia, most of South Australia, Victoria, parts of NSW and the southern section of the Queensland grain belt (Fig. 3).

As pointed out by Nix (1975), there is good reason for the $P: E$ ratio from South Australia to have less value in central and northern NSW and be close to meaningless in central Queensland. Nevertheless, extending this line across the Australian grain belt will indicate where this relationship breaks down. The $P: E$ ratio varies slightly for a range of towns on the edge of the Australian grain belt from Western Australia across the southern states to NSW and Queensland (Fig. 4, Table 2). The growing season rainfall is lowest at Waikerie $(175 \mathrm{~mm})$ and Mildura $(174 \mathrm{~mm})$, but these locations also have lower potential evaporation than other sites in southern regions of the grain belt, primarily due to their more southerly position. There is considerable year to year variability in the $P: E$ ratio at all sites but this tends to increase anticlockwise around the grain belt from Western Australia to Queensland.

\subsection{Simulated wheat growth using APSIM}

APSIM wheat yield simulations for every second $10 \mathrm{~km}$ buffer zone surrounding Goyder's Line in the Eastern EP and Upper North using the Calcarosol soil are shown in Fig. 5a,b respectively. As expected, there is a decline in simulated yield across the tran-

Table 2. Mean precipitation $(P ; \mathrm{mm})$, mean evaporation $\left(E_{;} \mathrm{mm}\right)$ and coefficient of variation $(\mathrm{CV}$, calculated as SD divided by the mean) for $P: E$ ratio in the selected locations

\begin{tabular}{|lccc|}
\hline Locations & $P$ & $E$ & CV of $P: E(\%)$ \\
\hline Sth Cross & 222 & 826 & 35 \\
Minnipa & 242 & 862 & 39 \\
Orroroo & 234 & 743 & 42 \\
Waikerie & 175 & 642 & 44 \\
Mildura & 174 & 773 & 48 \\
Walgett & 229 & 799 & 53 \\
St George & 229 & 859 & 55 \\
\hline
\end{tabular}




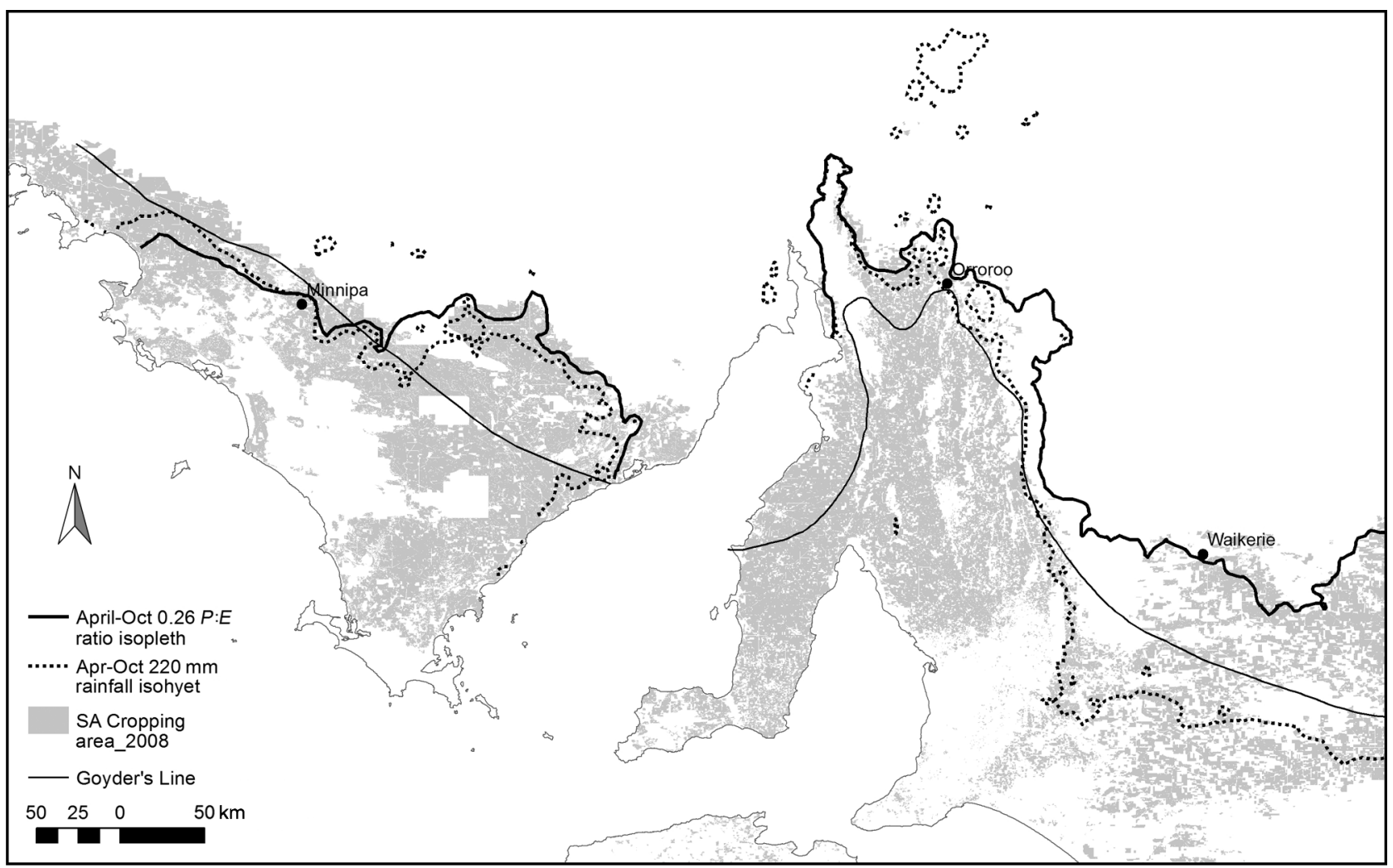

Fig. 2. Goyder's Line in relation to 0.26 precipitation:evaporation $(P: E)$ ratio isopleth and 220 mm isohyte for Apr-Oct in South Australia (SA)

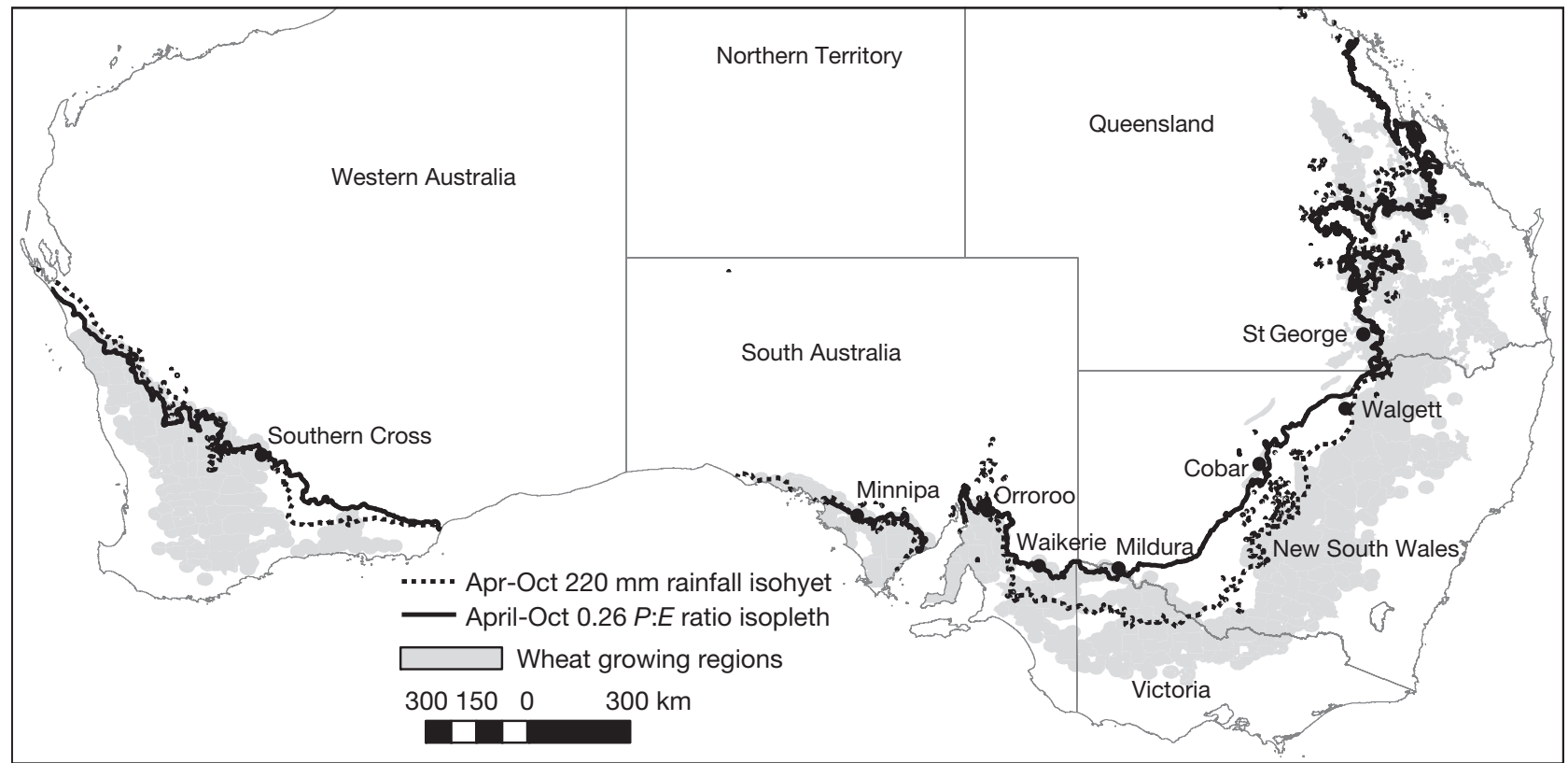

Fig. 3. Precipitation:evaporation $(P: E)$ ratio of 0.26 line and $220 \mathrm{~mm}$ rainfall isohyte for Apr-Oct drawn across the Australian wheat growing regions 


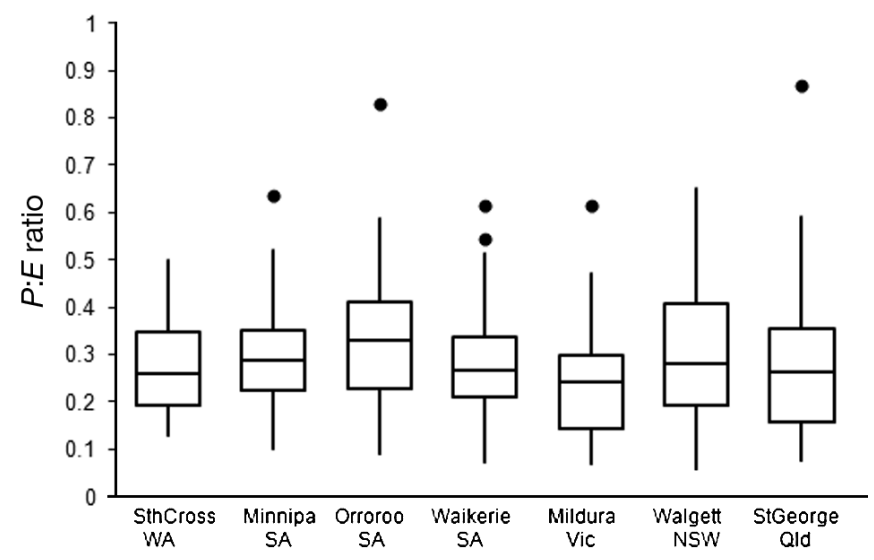

Fig. 4. Range in precipitation:evaporation $(P: E)$ ratio for 1970-2009 for sites in Fig. 3. Boxes: median and interquartile range (IQR) between 25th and 75th percentile. Whiskers: range up to $\pm 1.5 \times \mathrm{IQR}$, closed circles: outliers up to $\pm 3 \times$ IQR. SA: South Australia, NSW: New South Wales, Qld: Queensland, WA: Western Australia, Vic: Victoria

sect from south to north. On eastern EP, the largest decline in median yield occurs between 60 and $80 \mathrm{~km}$ north of Goyder's Line, which corresponds with the edge of the cropping zone (Fig. 2). In contrast, there is a steadier drop in yield across Goyder's Line in the Upper North, with the largest decline between 20 to $40 \mathrm{~km}$ north of the line. The spatial pattern of decline was similar for the 2 other soil types (not shown).

\subsection{Climate change impacts on shifts in margin}

The OzClim projections of annual temperature and rainfall for the South Australia grain region are given in Table 3.

Fig. 6 illustrates the result of generating $0.26 P: E$ ratio isopleths from both CSIRO Mk3.5 and CC MIROC-H models for 2030 and 2050. For 2030, both the models indicate a southward shift of $0.26 P: E$ ratio isopleths in Western EP while in eastern EP there is a marginal shift to the south. In the Upper North, both models align with the boundary of current cropping areas. In the Murray Mallee, CSIRO Mk 3.5 indicates a noticeable southward shift of the $0.26 P$ : $E$ ratio isopleth. Interpreting this shift in other words could mean that what is currently a $P: E$ ratio of 0.30 could be the future 0.26 in the Murray Mallee using the CSIRO MK3.5 model. The $0.26 P$ :E ratio isopleth generated from the CC MIROC-H model follows the current cropping boundary for 2030. For 2050, CSIRO Mk 3.5 model indicates a significant southward shift of the $0.26 P$ :E ratio isopleth in the EP and Murray Mallee. In the EP, the CSIRO Mk3.5 model indicates that by 2050, the $0.26 P$ :E isopleth will be where the current $0.35 P: E$ isopleth is. The projections from the wetter model, CC MIROC-H, do not suggest a large shift.

\section{DISCUSSION}

Goyder was an observant surveyor who travelled on horseback; while he had access to the experience of pioneer graziers, he only had access to the limited rainfall records that existed at the time. Policy makers today have access to easy road transport, satellite imagery, computer data-bases of production, extensive climate records and daily simulations of $100 \mathrm{yr}$ of crop growth and yield. The fact that Goyder's Line drawn in 1865 still approximates much of the boundary between low rainfall cropping and the pastoral zone in South Australia is a testament to Goyder's judgement.
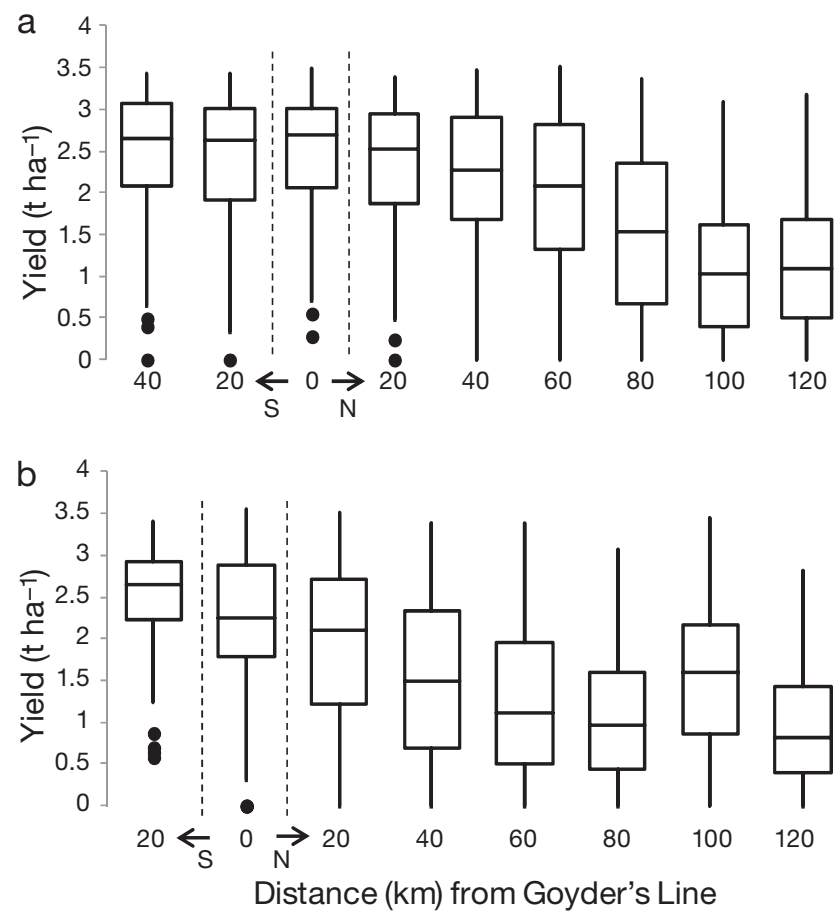

Fig. 5. Simulated wheat yield distributions for 'Calcarosol' soil at locations passing through Goyder's Line (0) to $120 \mathrm{~km}$ (120) north of Goyder's Line in (a) the Eastern Eyre Peninsula and (b) the Upper North region, South Australia. Boxes: median and interquartile range (IQR) of yields between the 25th and 75th percentile; whiskers: all yields up to $\pm 1.5 \times \mathrm{IQR}$; circles: outliers $> \pm 1.5 \times \mathrm{IQR}$. See Fig. 4 for plot symbols 


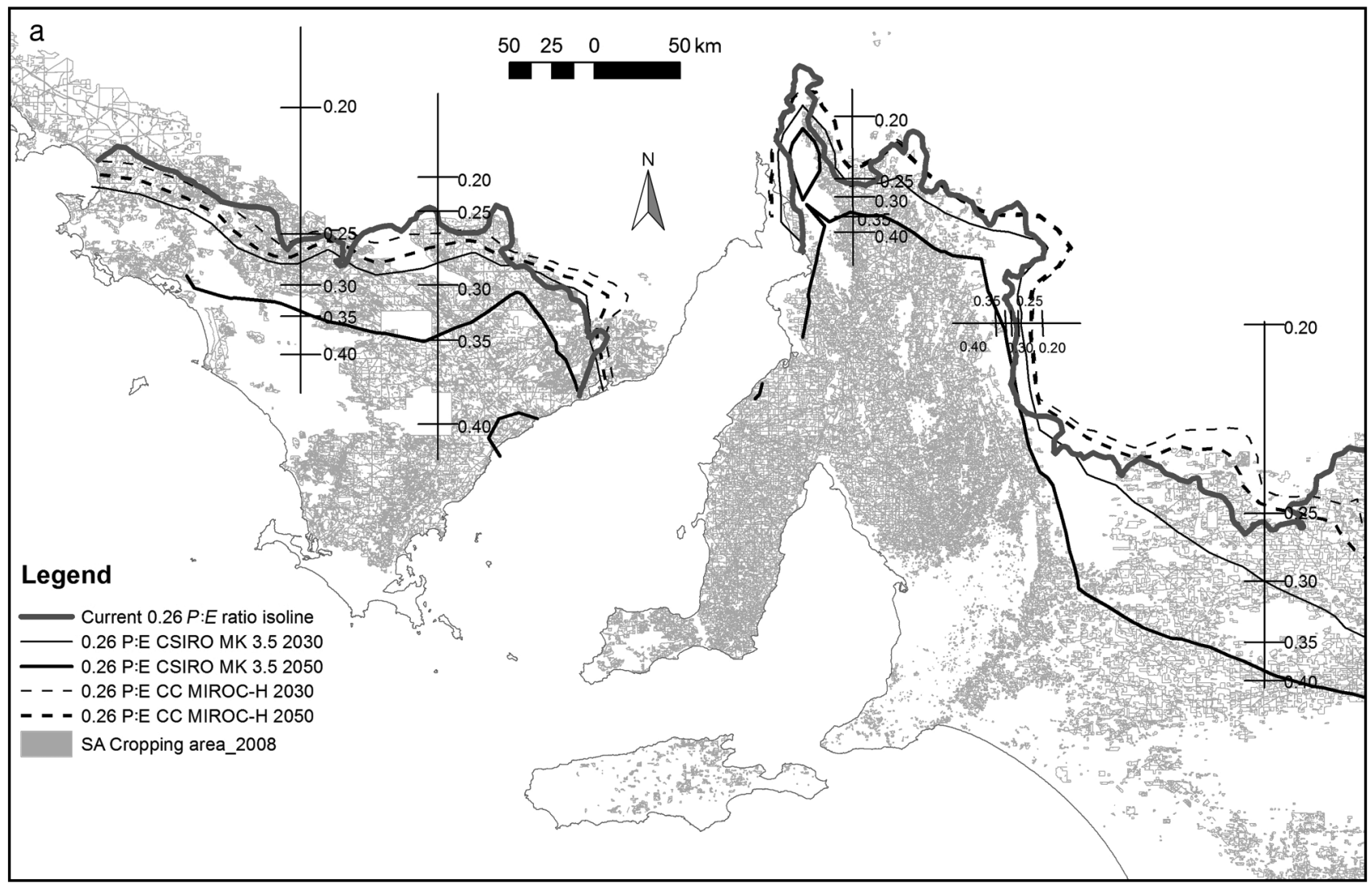

Fig. 6. Precipitation:evaporation ( $P: E$ ) ratio of 0.26 , generated for 2030 and 2050 using CSIRO Mk3.5 and CC MIROH-H climate models. Transect values $=P: E$ ratios of current climate along Goyder's Line in South Australia (SA)

Table 3. Climate change projections for the South Australian grain regions based on CSIRO Mk3.5 and CC MIROC-H models for 2030 and 2050. Temperature (Temp): mean annual change $\left({ }^{\circ} \mathrm{C}\right)$ from base; rainfall (Rain): change from base climate (\%; base climate is for 1980-1999). For these projections, we used the A1FI emission scenario and assumed the rate of global warming to be moderate. EP: Eyre Peninsula

\begin{tabular}{|lcccc|}
\hline & \multicolumn{3}{c}{ CSIRO Mk3.5 } & \multicolumn{2}{c|}{ CC MIROC-H } \\
& Rain & Temp & Rain & Temp \\
& & & & \\
$\mathbf{2 0 3 0}$ & & & -3 & +0.7 \\
Western EP & -10 & 1 & -3.5 & +0.7 \\
Eastern EP & -10 & 1 & -2.5 & +0.7 \\
Southern Flinders Coastal Plain & -12 & 1 & -1.5 & +0.7 \\
Upper Yorke & -10 & 1 & -0.20 & +0.7 \\
Upper North & -12 & 1 & -1 & +0.7 \\
Eastern Fall & -12 & 1 & -0.9 & +0.7 \\
Murray Mallee & -14 & 1 & -1 & \\
2050 & & & & \\
Western EP & -17 & 2 & -6 & +1.5 \\
Eastern EP & -20 & 2 & -6 & +1.5 \\
Southern Flinders Coastal Plain & -24 & 2 & -5 & +1.5 \\
Upper Yorke & -23 & 2 & -3 & +1.5 \\
Upper North & -25 & 2 & -0.5 & +1.5 \\
Eastern Fall & -25 & 2 & -2 & +1.5 \\
Murray Mallee & -28 & 2 & -2.5 & +1.5 \\
\hline
\end{tabular}

This study compared Goyder's Line to boundaries of pre-European vegetation (not shown here), the current extent of cropping (Fig. 1), soil type, rainfall, $P: E$ ratio (Fig. 2) and APSIM-modelled wheat yield. All of these boundaries correspond to at least some sections of Goyder's Line. This is to be expected given the strong interaction between topography and distance from the coast. However, we were unable to find any single environmental proxy that consistently matched Goyder's Line. We could not support an assertion that Goyder's Line was the boundary of Mallee and salt bush vegetation, the $300 \mathrm{~mm}$ annual rainfall isohyet, the $220 \mathrm{~mm}$ growing season isohyet, an isopleth of $P: E$ ratio of 0.26 , or a point of simulated wheat yield or risk of failing to achieve a certain yield.

It may be the case that finer scale vegetation, soil or climate data would lead to an environmental proxy with a closer fit to Goyder's Line. In particular, when Goyder's Line is compared with the $220 \mathrm{~mm}$ rainfall isohyet 
and the $P: E$ ratio of 0.26 (Fig. 2), it does not match consistently. While Goyder's Line is close to the 0.26 $P: E$ ratio at many points such as Minnipa in western EP and Orroroo in Upper North, there are other sections where Goyder's Line under-estimates cropped areas consistently more than the $0.26 P$ : $E$ isopleth ratio. The transects of $P: E$ ratios in Fig. 6 show that on eastern EP, Goyder's Line is closer to a $P: E$ ratio of 0.36 and in Murray Mallee to 0.33 . This lack of internal consistency should caution against using Goyder's Line as an agro-ecological isopleth or an isopleth of grain farming risk.

Perhaps the most relevant comparison is between Goyder's Line and current wheat farm locations. Although the line is a reasonable geographic estimate of the northern boundary of the grain belt, there are consistent anomalies in the location of the line (Fig. 1). Grain farmers, especially those in eastern EP, Upper Yorke Peninsula and Murray Mallee are aware that they are 'outside' (north of) Goyder's Line. These farmers acknowledge that they are farming in a high-risk environment, but argue that the line is in the 'wrong place' and they are taking no greater climatic risks than other farmers in the low rainfall zone who are on the 'safe' side of Goyder's Line (McCormack 2009). This assertion is supported by climate analysis shown in Fig. 2 and APSIM simulations for the 7 segments (EP and Upper North shown in Fig. 5a,b).

An unexpected result from this study was that a single measure of $P: E$ ratio of 0.26 matches with the drier edge of not only the South Australian grain belt but much of the rest of the Australian grain belt. This ratio was originally selected for the Minnipa research station and was based on Trumble's analysis in the 1930s. The ratio seems to work for strongly winter dominant Mediterranean climates in West and South Australia through more seasonally uniform rainfall in NSW, to a subtropical climate in Queensland. The robust $0.26 P$ : $E$ isopleth result is surprising because it is a simple measure of climate and only considers the growing period (April to October); no account is taken of the substantial summer rainfall in northern NSW and southern Queensland, nor the timing of rainfall events through the season, nor the direct measure of temperature on phenology and wheat crop heat stress. There are some anomalies such as south east West Australia and southern NSW where the edge of the grain belt is more conservative than the $P$ : $E$ ratio. These areas warrant further study, in order to explore the possibility of expansions of cropping areas, which is beyond the scope of this paper. Only in central Queensland, which is a strongly summer dominant rainfall environment, does the edge of the grain belt extend well inland of the $P: E$ ratio. We expected to find many more anomalies between the edge of the grain belt and the $P: E$ ratio given the differences in productivity measures (Kokic et al. 2006) seasonality of climate, size of rainfall events (Sadras \& Rodriguez 2007), history of development, technologies available, level of risk aversion of different communities and even the level of drought support, which historically has differed from state to state (Botterill 2003).

Soil type is an important consideration for low rainfall cropping. In more northern regions of Australia, the drier edge of the grain belt benefits from fine textured soils with a high water holding capacity where water can be stored during the summer wet season. In the south of the country and in West Australia, recent droughts have highlighted that soils with lighter textured surfaces have performed better than soils with heavier texture. This is most likely due to lower amounts of soil evaporation (Gregory et al. 2000). Despite the importance of soil type, the close relationship between the $0.26 P: E$ isopleth and the margin of the grain belt indicates that the margin is determined more strongly by climate, and soil type makes a small contribution to defining the boundary.

Climate change projections for South Australia indicate a general drying and warming trend for 2030 and beyond (CSIRO 2003, 2007), and obviously this is concerning for those farming enterprises on the hot, dry edge of the grain belt. It is also a concern for grain production across all of the grain belt with implications for food security. However, it is important to not over-interpret Fig. 6 as a confident prediction of the location of the future grain belt. Rather, it is to be seen as a representation of the possible location of the $0.26 P$ : $E$ isopleth under different climate change projections. Not only are the projections uncertain, there is much that is unknown about future technologies. Farmers have developed effective climate risk management and there is increased focus on developing effective adaptation options to climate change that may tend to moderate land use changes (Doudle et al. 2009). For example, the introduction of zero-tillage has enabled increased water use efficiency (Kirkegaard \& Hunt 2010), and further technological and managerial advances are possible. Similarly, elevated atmospheric carbon dioxide concentrations can increase crop growth and yield especially under dry conditions, reducing risks of land-use change under climate change (Howden \& Reyenga 2001). However, a warming and drying trend will not just bring drought, it is expected to manifest 
in increased aridity. While many farm enterprises in these regions have been resilient during drought and productive in good seasons, there is little evidence of expansion beyond the existing edge of the grain belt.

The main finding of this paper is that the drier margin of the Australian grain belt may be a climatically determined 'hard edge'. We arrived at this conclusion by considering Goyder's Line, developed almost $150 \mathrm{yr}$ ago, the $P: E$ ratio suggested by Trumble (1939), applied by French (1988) to Minnipa, and now by extending the $0.26 P: E$ isopleth across the Australian grain belt. If this finding is correct, it follows that a warming and drying trend will shift the $0.26 P$ : $E$ isopleth and hence the edge of the grain belt towards the coast. Although we are cautious about projecting where this shift will be, the transects of $P: E$ ratio in Fig. 6 show that while there is uncertainty in future projections, the area affected for a given change in $P: E$ can be predicted. Regions such as the Eastern Fall and South Flinders coastal zone have strong gradients of topography, climate, soils and vegetation, crop production and hence land values. In these sites, there will likely be smaller changes in location of the $P: E$ isopleth. However, as can be seen in the transect of the current $P: E$ in Fig. 6, most of the grain belt in EP and the Murray Mallee is on an extensive plain with widely spaced isopleths of $P: E$. When climate change is measured in a southerly shift $\left(\mathrm{km} \mathrm{decade}^{-1}\right)$ of the $0.26 P: E$ ratio isopleth, the fastest rate of change will be across relatively flat plains. This rate of change may be a challenge for individual farm enterprises, communities and governments.

Low rainfall farming communities acknowledge that they are farming in a risky environment, and most maintain that they can cope with the early stages of a warming and drying trend with current and future technologies (Doudle et al. 2009). The surprising but concerning finding from this study is that so many low rainfall farming communities around Australia are on a similar climatic edge. This does not mean that there is no future for low rainfall farming regions, but it does mean that there are no obvious Australian grain farming regions that low rainfall farmers in South Australia can visit to get an idea of how their farming future may look.

Acknowledgements. The work presented here is part of a project funded by the Australian Government Department of Agriculture, Fisheries and Forestry's (DAFF) Caring for our Country, CSRIO Climate adaptation flagship, DAFF Australia's Farming Future and the South Australian Government's Premier's Science Research Fund (PSRF) Transect for Environmental Decision Making. We thank Dr. M.
Robertson and Dr. R. Llewellyn from CSIRO for useful suggestions to improve the manuscript, and Dr. G. McDonald from the Waite Institute for alerting us to the paper by Marshall and the work of Trumble and other Waite scientists on $\mathrm{P}: \mathrm{E}$ ratios in the 1930s. We thank the anonymous reviewers for their insightful comments which helped to improve the manuscript.

\section{LITERATURE CITED}

Alexander BM, Hayman PT (2008) Talking about the weather: APSIM, climate change and grain farmers on the Upper Eyre Peninsula, SA. Unkovich M (ed) 14th Aus Agronomy Conference, Adelaide

ANRA (2001) Agriculture - context for sustainable natural resource management - Australia. www.anra.gov.au/ topics/agriculture/climate-soil/index.html (accessed March 9, 2011)

Botterill LC (2003) Government responses to drought in Australia. In: Botterill LC, Fisher M (eds) Beyond drought: people, policy and perspectives. CSIRO publishing, Melbourne, p 49-66

Carter JO, Flood NF, Danaher T, Hugman P, Young R (1996) Development of data rasters for model inputs. In: Development of a national drought alert strategic information system, Vol. 4. Final Report on QPI 20 to LWRRDC

Clark AH (1962) Editor's note. In: Meinig DW (1962) On the margins of good earth: the South Australian wheat frontier. Association of American Geographers. Rand McNally, Chicago, IL

Crawford RMM (2008) Plants at the margin: ecological limits and climate change. Cambridge University Press, Cambridge

CSIRO (2003) Assessment of climate change, impacts and possible adaptation strategies relevant to South Australia, available at www.sa.gov.au/upload/franchise/ Water,\%20energy \%20and \%20environment/climate_ change/documents/what_is_cc/CSIRO_Report_CC_in_ SA2003.pdf

CSIRO (2007) Climate change in Australia. TechRep, available at www.climatechangeinaustralia.gov.au/documents/ resources/TR_Web_FrontmatterExecSumm.pdf

Davidson BR (1981) The economics of the margin. In: de Kantzow DR, Sutton BG (eds) Cropping at the margin: potential for overuse of semi-arid lands. Australian Institute of Agricultural Science, Sydney, p 22-29

De Martonne E (1926) Une nouvelle fonction climatologique: l'indice d'aridité. Meteorologie 2:449-458

DENR (2009) Pre-European settlement vegetation (floristic)-agricultural region (incomplete). Department of Environment and Natural Resources, Adelaide (http:// envapps.sa.gov.au/sim/dataSet-display.do? cmd=DataSet Dto\&dsNumber=1240; accessed May 4, 2011)

Doudle S, Hayman PT, Wilhelm N, Alexander BM (2009) Farmer's capacity to adapt to climate change: SA case studies. Agric Sci 21:13-19

Fischer G, Van Velthuizen $H$, Shah M, Nachtergaele F (2002) Global agroecological assessment for agriculture in the 21st century: methodology and results. International Institute for Applied Systems Analysis, Laxenburg, available at www.iiasa.ac.at/Research/LUC/SAEZ/index. html (accessed May 5, 2011)

French RJ (1988) The greenhouse effect and its implications for primary production in South Australia. In: Dendy $\mathrm{T}$ (ed) Adelaide Greenhouse '88 Conf. Department of Environment and Planning, Adelaide, p 137-140 
Gregory PJ, Simmonds LP, Pilbeam CJ (2000) Soil type, climatic regime, and the response of water use efficiency to crop management. Agron J 92:814-820

Hammer GL, Woodruff DR, Robinson JB (1987) Effects of climatic variability and possible climatic change on reliability of wheat cropping: a modelling approach. Agric For Meteorol 41:123-141

Hayman PT, Whitbread A, Gobbett D (2010) The impact of El Nino Southern Oscillation on seasonal drought in the southern Australian grainbelt. Crop Pasture Sci 61: 528-539

Howden SM, Reyenga PJ (2001) Global change impacts on wheat production along an environmental gradient in New South Wales. In: Ghassemi F, Whetton P, Little R, Littleboy $M$ (eds) Integrating models for natural resources management across disciplines, issues and scales. MSSANZ, Canberra, p 661-666

> Hutchinson MF, McIntyre S, Hobbs RJ, Stein JL, Garnett S, Kinloch J (2005) Integrating a global agro-climatic classification with bioregional boundaries in Australia. Glob Ecol Biogeogr 14:197-212

Inakwu O, Odeh A, Tan DKY, Ancev T (2011) Potential suitability and viability of selected biodiesel crops in Australian marginal agricultural lands under current and future climates. Bioenerg Res 4:165-179

Jeffrey SJ, Carter JO, Moodie KB, Beswick AR (2001) Using spatial interpolation to construct a comprehensive archive of Australian climate data. Environ Model Softw 16:309-330

Keating BA, Carberry PS, Hammer GL, Probert ME and others (2002) An overview of APSIM, a model designed for farming systems simulation. Eur J Agron 18:267-288

Kirkegaard JA, Hunt JR (2010) Increasing productivity by matching farming system management and genotype in water limited environments. J Exp Bot 61:4129-4143

Kokic P, Davidson A, Rodriguez VB (2006) Australia's grains industry: factors influencing productivity growth. Australian Bureau of Agricultural Research, Res Rep 06.22, Canberra

Loarie SR, Duffy PB, Hamilton H, Asne GP, Field CP, Ackerly DD (2009) The velocity of climate change. Nature 462:1052-1055

Luo Q, Jones RN, Williams M, Bryant B, Bellotti W (2005) Probabilistic distributions of regional climate change and the application in risk analysis of wheat production. Clim Res 29:41-52

Marshall A (1973) The use and misuse of the 'length of growing period' concept. Aust Geographer XII 12(4): 334-339

Maschmedt DJ (2002) Assessing agricultural land. Soil and Land Program, Dept of Water, Land and Bio-diversity Conservation South Australia

McCormack J (2009) Life on Goyder's Line. Aust Geogr 21

Meinig DW (1961) Goyder's line of rainfall: the role of a geographic concept in South Australian land policy and agricultural settlement. Agric Hist 35:207-214

Meinig DW (1962) On the margins of good earth: the South Australian wheat frontier 1869-1884. Association of American Geographers. Rand McNally, Chicago, IL

Nix HA (1975) The Australian climate and its effects on grain yield and quality. In: Lazenby A, Matheson EM (eds) Australian field crops, Vol. 1. Wheat and other temperate cereals. Angus \& Robertson, Sydney, p 183-226

Padbury G, Waltman S, Caprio J, Coen G and others (2002) Agroecosystems and land resources of the Northern Great Plains. Agron J 94:251-261

Reyenga PJ, Howden SM, Meinke H, Hall WB (2001) Global change impacts on wheat production along an environmental gradient in South Australia. Environ Int 27: 195-200

Ricketts JH, Page CM (2007) A web based version of OzClim for exploring climate change impacts and risks in the Australian region. In: Oxley L, Kulasiri D (eds) MODSIM 2007 International Congress on Modelling and Simulation. Modelling and Simulation Society of Australia and New Zealand, December 2007, p 560-566

Rogers A (2008) Weather prophets of South Australia: stories of the people of the Bureau of Meteorology. The Bureau of Meteorology, Adelaide

Root TL, MacMynowski DP, Mastrandrea MD, Schneider $\mathrm{SH}$ (2005) Human modified temperature induced species changes: joint attribution. Proc Natl Acad Sci USA 102: 7465-7469

Rosenzweig C, Karoly D, Vicarelli M, Neofotis P and others (2008) Attributing physical and biological impacts to anthropogenic climate change. Nature 453:353-357

- Sadras VO, Rodriguez D (2007) The limit to water-use efficiency in eastern Australia. II. Aust J Agric Res 58:657-669

Sadras VO, Baldock J, Roget DK, Rodriguez D (2003) Measuring and modelling yield and water budget components of wheat crops in coarse-textured soils with chemical constraints. Field Crops Res 84:241-260

Sheldrick J (2005) Goyder's Line: the unreliable history of the line of reliable rainfall. In: Sherrat $T$, Griffiths $T$, Robin L (eds) A change in the weather, climate and culture in Australia. National Museum of Australia Press, Canberra, p 56-65

Suppiah R, Preston B, Whetton PH, McInnes KL and others (2006) Climate change under enhanced greenhouse conditions in South Australia. Climate Impacts and Risk Group, CSIRO Marine and Atmospheric Research

Taylor G (1915) The climatic control of Australian production. Bureau of Meteorology, Bull No. 11, Government Printer, Melbourne

Taylor G (1918) The Australian environment (especially as controlled by rainfall). Advisory Council of Science and Industry, Melbourne

Trumble HC (1939) Climatic factors in relation to the agricultural regions of southern Australia. Trans R Soc S Aust 63:36-43

van Ittersum MK, Howden SM, Asseng S (2003) Sensitivity of productivity and deep drainage of wheat cropping systems in a Mediterranean environment to changes in $\mathrm{CO} 2$, temperature and precipitation. Agric Ecosyst Environ 97:255-273

Whetton PH, Hennessy KJ, Katzfey JJ, McGregor JL, Jones RN, Nguyen K (2001) Climate averages and variability based on a transient $\mathrm{CO}_{2}$ simulation. Annu Rep 1997-98, Department of Natural Resources and Environment, Melbourne

Whitbread AM, Hancock J (2008) Estimating grain yield with the French and Schultz approaches vs. simulating attainable yield with APSIM on the Eyre Peninsula. Proc 14th Agronomy Conf, 21-25 Sept 2008, Adelaide

Williams J, Hook RA, Hamblin A (2002) Agro-ecological regions of Australia: methodologies for their derivation and key issues in resource management. CSIRO Land and Water, Canberra, available at www.clw.csiro.au/ publications/general2002/Agro-eco_report_nomap.pdf

Yunusa IAM, Bellotti W, Moore AD, Probert ME, Baldock JA, Miyan SM (2004) An exploratory evaluation of APSIM to simulate growth and yield processes for winter cereals in rotation systems in South Australia. Aust J Exp Agric 44:787-800 